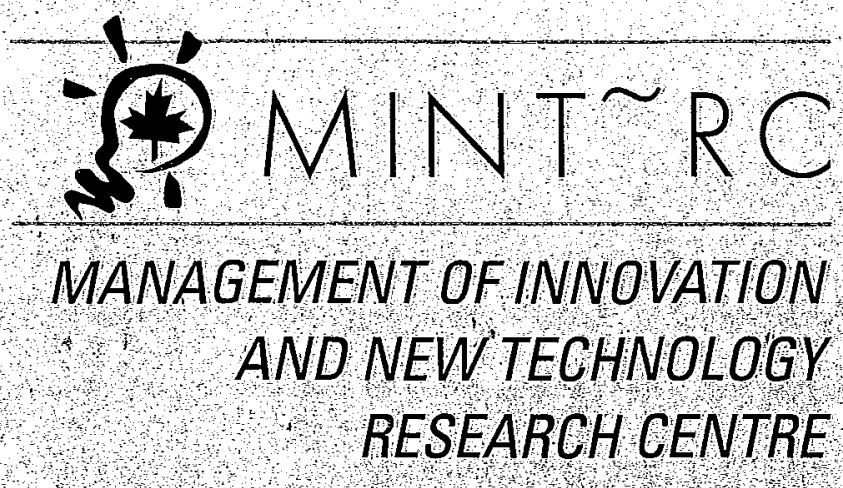

TEAM PERFORMANCE AND SATISFACTION:

A LINK TO COGNITIVE STYLE WITHIN

A PROCESS FRAMEWORK

by

Min Basadur

and

Milena Head

Management of Innovation and New Technology

Research Centre

WORKING PAPER NO. 103

March 2001

Innis

ras

HD

45

. .W657

no.103

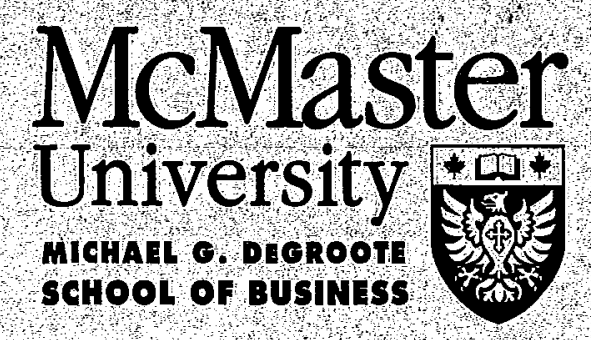




\title{
TEAM PERFORMANCE AND SATISFACTION: \\ A LINK TO COGNITIVE STYLE WITHIN \\ A PROCESS FRAMEWORK
}

\author{
by \\ Min Basadur \\ and \\ Milena Head \\ Management of Innovation and New Technology \\ Research Centre
}

WORKING PAPER NO. 103

March 2001

The Working Paper series is intended as a means whereby a researcher may communicate his or her thoughts and findings to interested readers for their comments. The paper should be considered preliminary in nature and may require substantial revision. Accordingly, this Working Paper should not be quoted nor the data referred to without the written consent of the author. Your comments and suggestions are welcome and should be directed to the author. 
Team Performance and Satisfaction: A Link to Cognitive Style Within a Process Framework

Min Basadur and Milena Head

Michael G. DeGroote School of Business

McMaster University

March 30, 2001 


\section{Team Performance and Satisfaction: A Link to Cognitive Style Within a Process Framework}

ABSTRACT

Effective teamwork is becoming increasingly important to organizational success. Advances in network and communication technology have allowed companies to widen their potential team member base, however we still need to better understand how to structure top-performing teams. This paper proposes forming teams based on their cognitive style, rather than personality, within a process framework.

An experiment was conducted to investigate the innovative performance of problem solving groups with three different blends of cognitive styles. As predicted, groups with a heterogeneous blend of styles outperformed groups with completely or partially homogeneous blends. On the other hand, team members' satisfaction scores were lower for heterogeneous teams than either the completely or partially homogeneous teams. There was preliminary evidence that among groups with heterogeneous blends, those with smaller style dispersions might be expected to outperform those with larger style dispersions. There was also room for some speculation that a curvilinear relationship might exist for team members' satisfaction as a function of diversity in team member cognitive style. Implications of these findings are discussed. 
Team Performance and Satisfaction: A Link to Cognitive Style Within a Process

Framework

\section{INTRODUCTION}

Why do some teams perform better than other teams? Hackman (1990) identified several key environmental factors in managing successful work groups in organizations, including time limits and deadlines; authority dynamics; motivational engagement of work content; specificity of goals and adequate organizational support. Barlow (2000) analyzed data from creative teams which suggested that complex analytical techniques, such as costed-function modeling and decision criteria matrix, and additional time in idea improvement and implementation planning, may have far more impact upon a team's creative effectiveness than frequently researched measures such as idea quantity. Guerin (1997) concluded teamwork effectiveness cannot be adequately understood without reference to the impact of unconscious dynamics on human behavior. Romig and Olson (1995) addressed the greater resistance to team development of knowledge workers compared to manufacturing workers.

Others have suggested that diversity in groups is important. If team members are too similar in their outlook, decisions can be made more easily, but overall effectiveness may suffer if differing opinions, perspectives, and methods are not presented (Janis, 1971). Brophy (1998) proposed a tri-level matching theory to integrate diverse accumulated theories and research findings and suggested that groups with different preferences and abilities, knowledge and work arrangements will best match the character of particular problems. Although strict empirical evidence may be lacking, authors argue that diversity of perspectives among group members can stimulate creative thought processes (Cox, 1991; Cox and Blake, 1991). Guzzo and 
Dickson (1996) also conclude that heterogeneity appears to be linked most strongly to team effectiveness for "creative and intellective tasks". Belbin (1993) claims that top performing teams have a full complement of personality types, and Kling (2000) suggests using team conflict to encourage creative solutions.

Kichuk and Wiesner (1998) postulate that while team member heterogeneity on some factors may be beneficial, homogeneity on some other factors may be required to maintain team harmony and productivity. Trust is often viewed as a prerequisite for effective team interaction (Meyerson et al, 1996). Mayer et al. (1995) have suggested that in order to establish a basis for trust, team members have historically relied on interpersonal similarity and common background and experience. As team members become more dissimilar, other initial sources of trust need to be developed as a starting point for teamwork. Austin (1997) suggested that there may be an optimal level of group diversity that will stimulate creative thinking and that the relationship between group diversity and creativity may be curvilinear.

Many organizations have routinely used personality-based instruments, which identify individual differences, as tools for team development, as well as career counseling, communications training, and other organizational development purposes. Over the last 25 years, a number of researchers have studied the usefulness of personality measures for these various organizational development purposes (Nowack, 1996). Although as a predictor of individual job performance, the validity of personality measures has been found to be rather low (Nowack, 1997), many organizations believe that providing individual information about personality types is useful in team building. Team members learn about managing their different perspectives related to their personality types. For example, the Myers Briggs Type Indicator (MBTI; Myers, 1994) 
Team Building Program provides members with a description of the group's personality type, team strengths and weaknesses, its problem-solving and conflict management style (Hirsch, 1992).

Personality characteristics have also been related to various team roles. For example, the early work of Belbin (1981) identified eight team roles in the Belbin Team Role Self-Perception Inventory (SPI), and later added a ninth (Belbin, 1993). Woodcock (1989) identified twelve roles, Margerison and McCann nine roles (1990), Spencer and Pruss ten roles (1992), and Davis et al. (1992) five team roles. Among many other approaches to improving team performance are the Personal and Team Roles Profile based on the Team Work cycle (Mumma, 1994), the Leadership Practices Inventory (Rouzes and Pozner, 1988), the Thomas Kilman Conflict Style (Phillips and Elledge, 1989), and the Johari Window (Filley, 1975).

Therefore, there is a large milieu of different theories and factors that could explain team performance, including personality. Most of these theories and factors need much more investigation. For example, Kichuk and Wiesner (1998) warn practitioners to exercise caution in the use of personality measures for team selection, in that the validity of such selection methodologies has not been well established. The purpose of this paper is to open up a different track. What is reported is a study which investigates a different basis for creating diverse teams for improved performance. Rather than blending different personality types, the focus is on blending different cognitive problem solving process styles.

One of the most important reasons that teams are so popular in organizations in these complex times is the need for faster and better problem solving and innovation. As complexity rises and the speed of business accelerates, problems requiring 
ingenuity can no longer be solved satisfactorily by individuals, or by sequentially processing by a series of individuals. Instead, multi-disciplinary teams of diverse individuals must work together in parallel. Therefore, one of the ways to characterize and study teams is as creative problem solving units. Team (and organizational) innovation can be defined as a continuous process of finding good problems, solving them and implementing valuable changes (Basadur, 1992). No matter what the context, successful teams discover, define, and solve problems and implement solutions better than unsuccessful teams. Of course, the word "problem" is used here generically. It includes all diverse interpretations such as, opportunity, unsatisfied need, gap, difficulty, crisis and desire for improvement (see Basadur, 1994). In this research, we investigate if there may be an optimal team mix of problem solving cognitive (thinking) styles within a problem solving framework. Cognitive style may be related to, but is distinct from personality. Perhaps teams can be formed based on their cognitive style within a process framework.

Perhaps there is a "magical mix" of team members, requiring that they be evaluated within the specific context of a problem solving process, rather than applying indirect approaches, such as personality traits.

\section{CREATIVE PROBLEM SOLVING AS A PROCESS}

The study of creativity has been often categorized into the four "P's": product, person, press (environment) and process (Murdock and Puccio, 1993). Basadur, Graen and Wakabayashi (1990) modeled organizational innovation as a continuous, dynamic,

circular four stage process of (1) Generating: discovering good problems to solve (deliberately seeking out new opportunities and viewing unsatisfactory situations as 
"golden eggs"); (2) Conceptualizing: defining those problems (crystallizing and understanding the key challenge); (3) Optimizing: developing new solutions; and (4) Implementing: putting the solutions into action. They divided the four stages into eight smaller steps. Each step contains a sequenced diverging and converging thinking miniprocess called ideation-evaluation (see Figure 1). The complete process is modeled in Figure 2, including the mini-process in each step, and is called the Simplex Creative Problem Solving (CPS) process. It extends earlier three and five step linear process models (Osborn, 1963; Parnes, Noller and Biondi, 1977) and was developed through real-world organizational field research and application experience (Basadur, 1974, 1979, 1992). Basadur, Graen and Green (1982) demonstrated that skill in applying each step of this process and the process as a whole could be deliberately developed. Additional supporting field research for the practicality of applying the process in organizations is summarized in Basadur (1982, 1987, 1994, 2000).

Basadur et al. (1990) also introduced the Creative Problem Solving Profile inventory (CPSP), which measures an individual's unique blend of preferences for the four stages of the Simplex CPS process. By plotting one's inventory scores on a two dimensional graph, one can display one's own preferred blend of the four different stages. One's largest quadrant on the two dimensional graph represents one's preferred or dominant style. The sizes of the other quadrants represents supporting orientations in turn. One's unique blend of styles is one's profile.

Figure 3 shows how individual differences in orientation can yield different creative problem solving process profiles. For example, if the area in quadrant 1 is larger than in the other three, the primary process style is generating; if quadrant 2, then conceptualizing; if quadrant 3 , then optimizing; and if quadrant 4 , then implementing. 
Figure 1

Ideation-Evaluation: A Sequential Two-Step Creative Thinking Mini-process

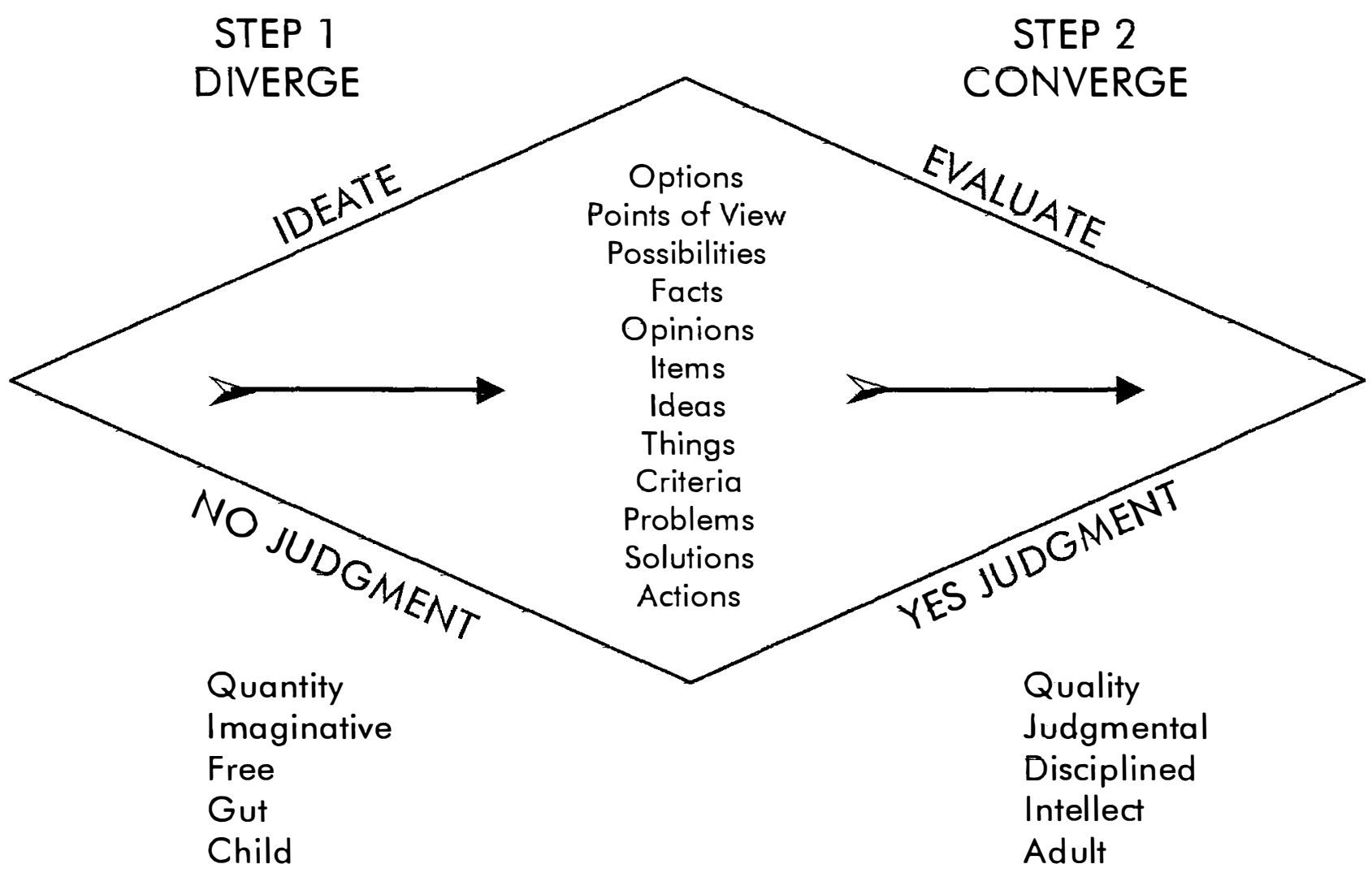


Figure 2

The Simplex Creative Process as a Whole

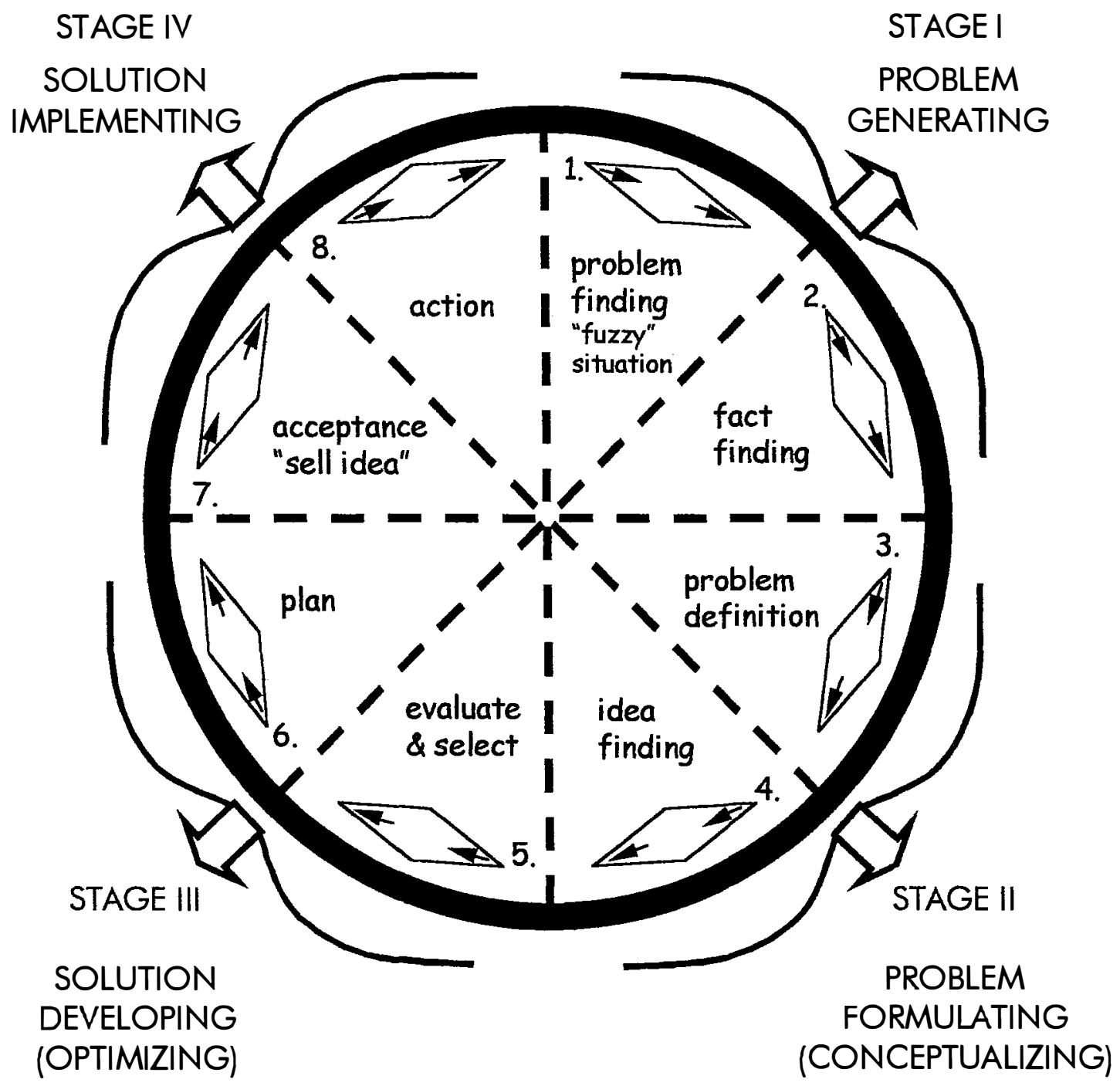


Figure 3

\section{Examples of Different Profiles of Creative Problem Solving With the Same Style Dominant and With Different Styles Dominant}

(All Four Examples Below Have The Generator Style Dominant)

Generator style dominant with all three other quadrants relatively small.

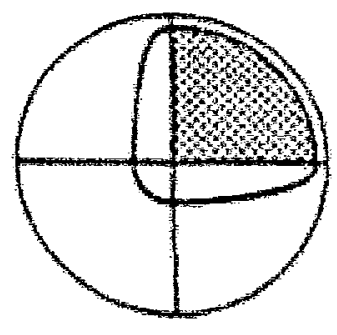

Generator style dominant with Implementer style as strong secondary.

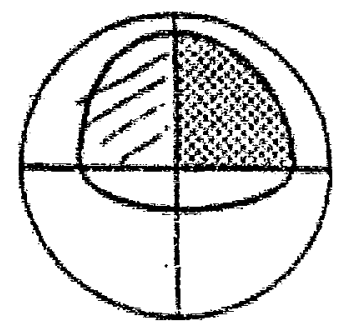

Generator style dominant with Conceptualizer style as strong secondary.

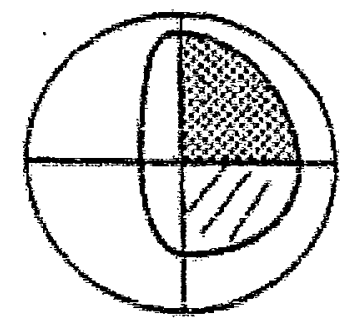

Generator style dominant with Conceptualizer and Implementer as secondary styles of significant and equal strength.
(All Four Profiles Below Have Different Styles Dominant)

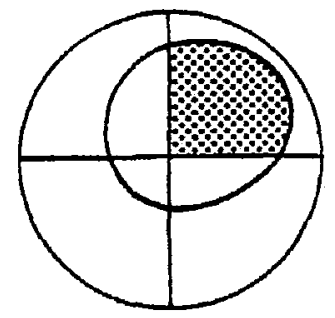

Generator style dominant with all three other styles relatively small.

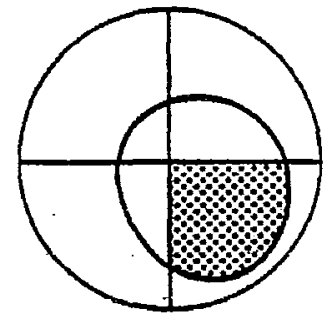

Conceptualizer style dominant with all three other styles relatively small.

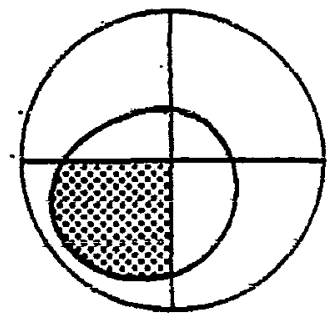

Optimizer style dominant with all three other styles relatively small.

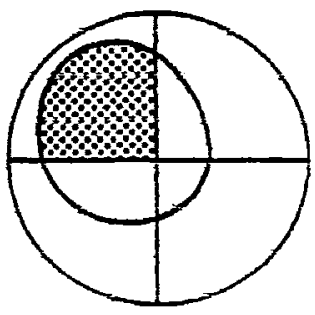

Implementer style dominant with all three other styles relatively small. 
Each of these styles reflects individual preferences for ways of gaining and using knowledge, as explained by Basadur et al (1990) and Basadur (1998a, 1998b), who described the CPSP's purpose, theoretical foundations, development, scoring, interpretation, reliability and validity.

\section{THE STUDY}

It has been natural to speculate that teams with a more balanced mix of the four CPSP styles would be more successful in innovative problem solving than teams with less balance. This would be because all four styles in the complete Simplex process of creative problem solving would be represented and thus, all four stages of the complete process would be more likely to be performed. On the other hand, team satisfaction might be expected to be lower in such a heterogeneous group due to the frustration that may arise from conflicting cognitive styles.

This study reports an experiment in which differential performance on an innovative task by teams with different mixes of CPSP styles was measured. This experiment examined if a team's mix of creative problem solving process styles could be linked to its performance on an innovative new product development task and also to the satisfaction the team members experienced in working together on the task.

\section{Hypotheses}

Three hypotheses were formulated based on speculations from past CPSP research and support from other authors, as outlined in the above literature review. 
Hypothesis 1: Heterogeneity

Teams whose members' dominant preferences for the different stages of the four stage Simplex creative problem solving process are such that a dominant preference for each of the four stages is represented will perform better than teams which have such representation in only one (homogeneous) or two (semihomogeneous).

Hypothesis 2: Dispersion within Heterogeneity

An optimal level of heterogeneity can be established for heterogeneous teams.

Hypothesis 3: Satisfaction

Job satisfaction will be lower for heterogeneous teams compared to more homogeneous teams.

\section{$\underline{\text { Research Design }}$}

A sample of 196 MBA students was administered the CPSP then formed into 49 teams of four members each. The teams were deliberately set up to fall into one of four categories of CPSP profiles mix, as illustrated in Figure 4.

1. Heterogeneous, all four dominant styles present, but widely dispersed. All four dominant styles represented and the centers of gravity of the four profiles located relatively far from each other (Figure 4a).

2. Heterogeneous, all four dominant styles present, but narrowly dispersed. All four dominant styles represented but with centers of gravity located relatively near each other (Figure 4b). 
3. Homogeneous: only one dominant style present (Figure 4c).

4. Semi-Homogeneous: only two dominant styles present (Figure 4d).

Each team received the same innovative task to complete in the same length of time. The task, to create a new product or service which could be marketed, is fully described below. Four independent judges evaluated the quality of the output of each team. To motivate the teams to do their best, they were told that the best performing teams would be publicly recognized at the annual MBA awards ceremony.

\section{Procedure}

The participants were given training in the Simplex creative problem solving process for one day then assigned into their teams. The training was done in two separate groups of 96 and 100 participants each. The training is highly interactive and hands-on, and has been fully described elsewhere (Basadur et al., 1982). The assignment was to apply the complete process on an innovative task. The task was to identify a problem or unsatisfied need in "society as a whole", define the problem or unsatisfied need, create a new product or service which would solve defined problem, and develop a plan for implementation. The complete assignment instructions are provided in Appendix I. On the second day, the teams received additional training and completed the assignment. This additional training was interspersed in small segments throughout the day to help the teams use the process as they moved through it step by step. 
Figure 4: Four Categories of Team Profile Blends

a) Heterogeneous, Widely Dispersed

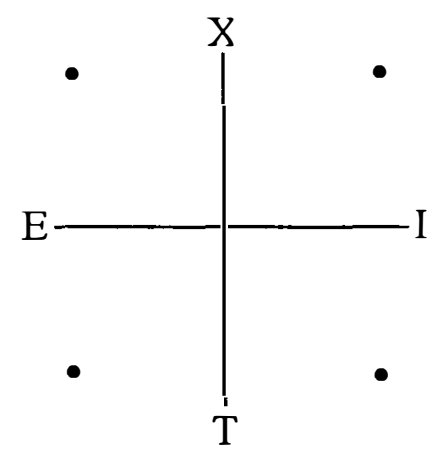

c) Homogeneous,

Three Dominant Styles Missing

(Example shown has Stage 4 present)

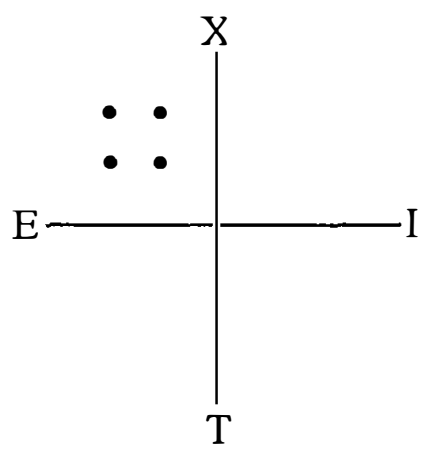

b) Heterogeneous, Narrowly Dispersed

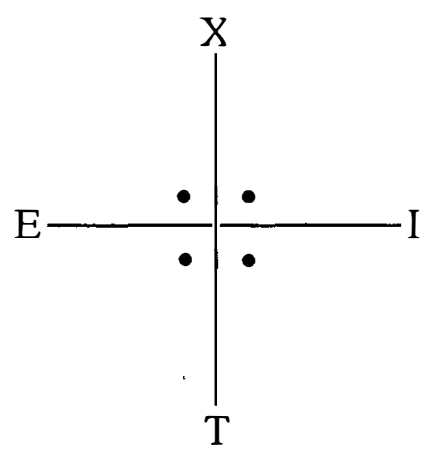

d) Semi-Homogeneous

Two Dominant Styles Missing and Two Opposing Styles Present (Example shown has Stage 2 and 4 present)

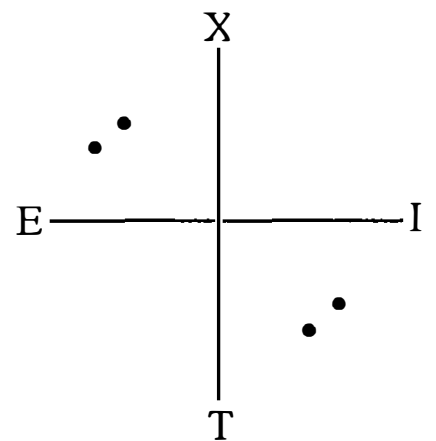


Data Analysis

Four independent judges used the Jackson and Messick (1964) criteria for assessment of the creativity of a product (unusualness, appropriateness, transformation and condensation), to rate the creative quality of each team's conceptualizing (key challenge) and optimizing (selected solution) output. The judges also rated the quality of each team's generating ("golden egg") and implementing (action plan) output (details in Appendix I). An overall average was also calculated for these four variables of the assignment. For example, the "golden egg" generated by a team might be "road rage". The crystallization into a key challenge might be "How to help drivers who are late for meetings reduce frustration in heavy stop and go traffic". The team's specific solution might be to market a "device installed in vehicles to measure and monitor the occupants' blood pressure and provide visible feedback to encourage relaxation and acceptance of the situation thus reducing frustration". The action plan for moving ahead toward market might, for example, include arranging for consumer research to evaluate the market potential and finding a developer of the device through the Internet. The evaluation form used by the judges is shown in Appendix II. Interjudge reliabilities were calculated for each of the four variable measures and for the overall average.

To test hypothesis 1, mean scores were calculated and compared for the innovative performance measures (golden egg, key challenge, selected solution, action plan, and overall) across the team categories (heterogeneous, semi-homogeneous, homogeneous). Significance was determined using the independent samples t-test for equality of means, where equal variances were not assumed.

To test hypothesis 2 , the heterogeneous teams $(n=15)$ were divided into two subcategories: widely dispersed $(n=9)$ and narrowly dispersed $(n=6)$ and the means for 
the innovative performance measures were compared. The Wilcoxon Mann-Whitney non-parametric test was used to determine significance among mean comparisons. Given the small sample sizes, this non-parametric test was used since it does not assume the difference between the samples is normally distributed.

Hypothesis 3 was tested by having individual team members fill out a Team Satisfaction Index Questionnaire. Significance was determined using the independent samples t-test for equality of means, where equal variances were not assumed. Team members rated their satisfaction with their team experience on a one to ten scale for (1) how well they worked together; (2) how much fun they had; (3) how much desire they had to work with their team again; and (4) how good they felt about the quality of the output. The results were averaged on each question by category (homogeneous, $n=85$; semi-homogeneous, $n=53$; heterogeneous, $n=57$ ).

\section{RESULTS}

The interjudge reliability results were $.77, .70, .65, .64$ and .78 , respectively for the four variables and overall, and support consistency in evaluation across the judges (see Table 1).

Heterogeneity (hypothesis 1)

Table 2 shows the mean innovative performance scores for teams with various blends of CPS profile styles. Mean scores generally increased as teams became more heterogeneous. This trend is graphically illustrated in Figure 5. Mean scores for the heterogeneous teams were significantly higher than mean scores for homogeneous and semi-homogeneous teams overall (4.22 vs 3.69 and 3.76 respectively, at $p<.05$ ) and on 
Table 1

Interjudge Reliability

\begin{tabular}{|ll|}
\hline Golden Egg: & .77 \\
Key Challenge: & .70 \\
Solution: & .65 \\
Action Plan: & .64 \\
Overall Evaluation: & .78 \\
\hline
\end{tabular}




\section{Table 2}

\section{Mean Innovative Performance Scores for Teams with Various Blends of CPS Profile Styles}

\begin{tabular}{|c|c|c|c|}
\hline $\begin{array}{l}\text { Measures of } \\
\text { Innovative } \\
\text { Performance }\end{array}$ & $\begin{array}{c}(\mathrm{a}) \\
\text { Teams with } \\
\text { Homogeneous Blends } \\
\text { (one stage } \\
\text { represented, } \\
\text { three stages missing) } \\
(\mathrm{n}=21)\end{array}$ & $\begin{array}{c}\text { (b) } \\
\text { Teams with } \\
\text { Semi-Homogeneous } \\
\text { Blends } \\
\text { (two stages represented, } \\
\text { two stages missing) } \\
(\mathrm{n}=13)\end{array}$ & $\begin{array}{c}\text { (c) } \\
\text { Teams with } \\
\text { Heterogeneous } \\
\text { Blends } \\
\text { (All four stages } \\
\text { represented) } \\
(n=15) \\
\end{array}$ \\
\hline Golden Egg & $\begin{array}{c}4.07 \\
(1.07)\end{array}$ & $\begin{array}{l}4.26 \\
(.75)\end{array}$ & $\begin{array}{l}4.45 \\
(.82)\end{array}$ \\
\hline Key Challenge & $\begin{array}{l}3.54 \\
(.82)\end{array}$ & $\begin{array}{c}3.58 \\
(.57)\end{array}$ & $\begin{array}{l}4.23^{\star a, b} \\
(.53)\end{array}$ \\
\hline Solution & $\begin{array}{l}3.96 \\
(.79)\end{array}$ & $\begin{array}{l}3.74 \\
(.95)\end{array}$ & $\begin{array}{l}4.23 \\
(.48)\end{array}$ \\
\hline Action Plan & $\begin{array}{l}3.03 \\
(.73)\end{array}$ & $\begin{array}{l}3.76^{\star^{a}} \\
(.81)\end{array}$ & $\begin{array}{l}3.97^{\star \star a} \\
(.61)\end{array}$ \\
\hline Overall & $\begin{array}{l}3.69 \\
(.64)\end{array}$ & $\begin{array}{l}3.76 \\
(.62)\end{array}$ & $\begin{array}{l}4.22^{\star a, b} \\
(.42)\end{array}$ \\
\hline
\end{tabular}

Legend: *a means significant difference vs homogeneous (a) at $p<.05$

$$
\begin{aligned}
& * \star a \text { means significant difference vs homogeneous }(a) \text { at } p<.001 \\
& \star a, b \quad \text { means significant difference vs both homogeneous }(a) \text { and semi-homogeneous }(b) \text { at } \\
& p<.05
\end{aligned}
$$




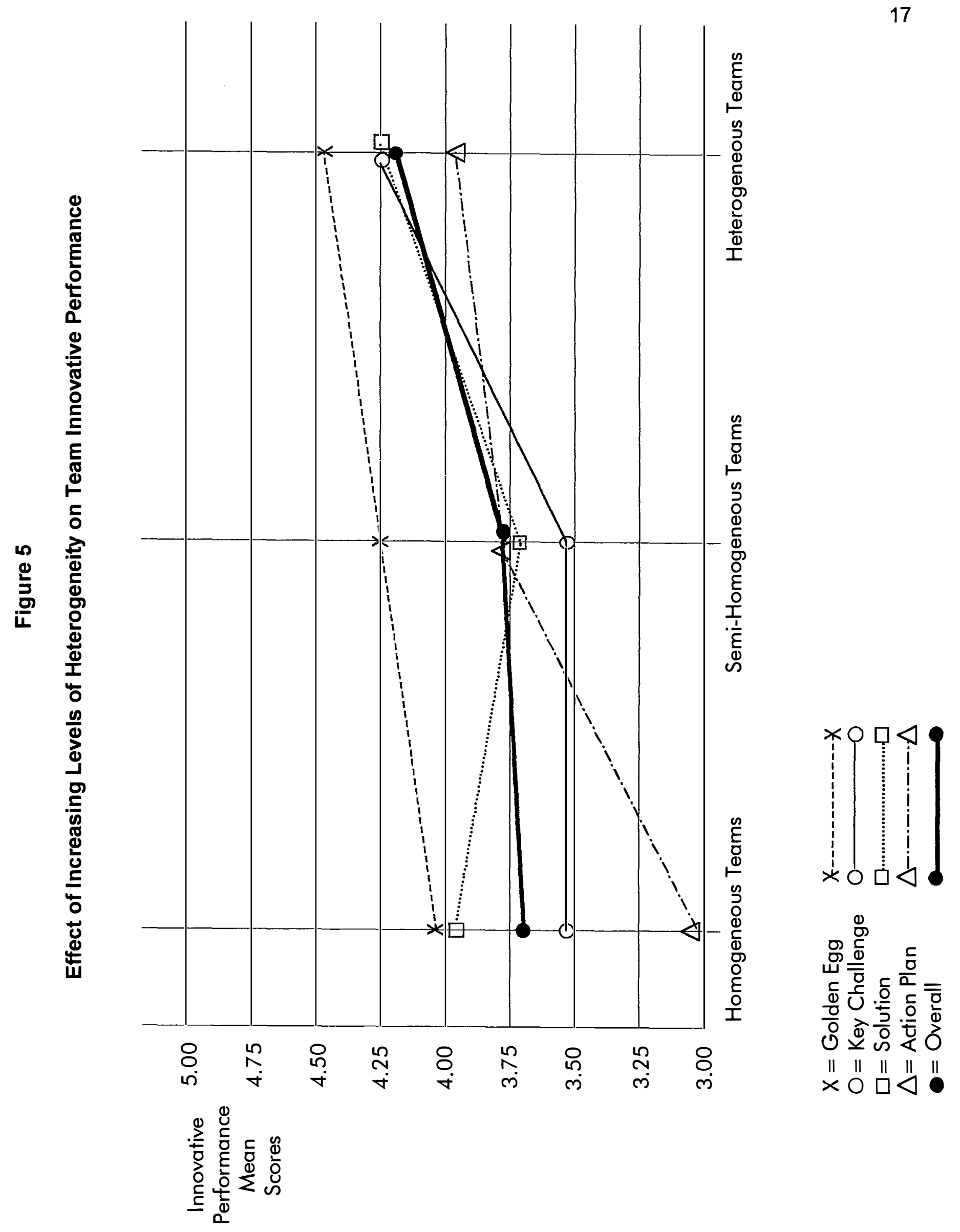


opportunity conceptualization ( 4.23 vs 3.54 and 3.58 respectively, $p<.05$ ). Mean scores for heterogeneous teams were also significantly higher than homogeneous teams for action planning for implementation (3.97 vs $3.03, p<.001)$. Semi-homogeneous team mean scores were similar to homogeneous team mean scores with the exception of action planning, where the semi-homogeneous teams were significantly higher (3.76 vs $3.03, p<.05)$. Table 3 displays the levels of statistical difference between pairwise comparisons of means.

\section{Dispersion within Heterogeneity (hypothesis 2)}

Performance means for the measures comparing the heterogeneous teams of narrow and wide dispersion were all directionally and consistently higher for the narrowly dispersed heterogeneous teams. Within our small sample sizes ( $n=9$ for wide dispersion; $n=6$ for narrow dispersion) statistical significance was not established for any of the comparisons. Table 4 and Figure 6 display the results.

\section{Satisfaction (hypothesis 3)}

The team satisfaction mean scores on all four measures of team member satisfaction were virtually in reverse to the team performance scores. On every measure, the heterogeneous team members' satisfaction means were the lowest. They were significantly lower on three measures than the semi-homogeneous teams and on two measures compared to the homogeneous teams (see Table 5).

In addition, while there were no significant differences between the homogeneous and semi-homogeneous teams on any of the four satisfaction questions, the semi-homogeneous scores were directionally higher on three of the four individual 


\section{Table 3}

\section{Levels of Significance in Differences Within Painwise Comparisons of Means}

\begin{tabular}{|l|c|c|c|}
\hline \multicolumn{1}{c|}{$\begin{array}{c}\text { Measures of } \\
\text { Innovative } \\
\text { Performance }\end{array}$} & $\begin{array}{c}\text { a vs b } \\
\text { Homogeneous vs } \\
\text { Semi-Homogeneous }\end{array}$ & $\begin{array}{c}\text { bemi-Homogeneous } \\
\text { vs Heterogeneous }\end{array}$ & $\begin{array}{c}\text { a vs c } \\
\text { Homogeneous vs } \\
\text { Heterogeneous }\end{array}$ \\
\hline Golden Egg & 0.557 & 0.531 & 0.244 \\
\hline Key Challenge & 0.853 & $\mathbf{0 . 0 0 5 ^ { \star }}$ & $\mathbf{0 . 0 0 4}^{\star}$ \\
\hline Solution & 0.506 & 0.114 & 0.213 \\
\hline Action Plan & $\mathbf{0 . 0 1 4 ^ { * }}$ & 0.456 & $\mathbf{0 . 0 0 0 ^ { \star * }}$ \\
\hline Overall & 0.745 & $\mathbf{0 . 0 3 5 ^ { \star }}$ & $\mathbf{0 . 0 0 5 ^ { \star }}$ \\
\hline
\end{tabular}

Note: * denotes statistical significance at $p<.05$

** denotes significance at $p<.001$ 
Table 4

Comparing Innovative Performance Means of Widely and Narrowly Dispersed Heterogeneous Teams

\begin{tabular}{|l|c|c|c|}
\cline { 2 - 4 } \multicolumn{1}{c|}{} & \multicolumn{2}{|c|}{ Mean Score } & \multicolumn{1}{c|}{} \\
\hline $\begin{array}{c}\text { Measures of Innovative } \\
\text { Performance }\end{array}$ & $\begin{array}{c}\text { Heterogeneous } \\
\text { Teams } \\
\text { Wide Dispersion } \\
(\mathrm{n}=9)\end{array}$ & $\begin{array}{c}\text { Heterogeneous } \\
\text { Teams } \\
\text { Narrow Dispersion } \\
(\mathrm{n}=6)\end{array}$ & Significance \\
\hline Golden Egg & $\begin{array}{c}4.37 \\
(.67)\end{array}$ & $\begin{array}{c}4.56 \\
(1.07)\end{array}$ & 0.636 \\
\hline Key Challenge & $\begin{array}{l}4.11 \\
(.40)\end{array}$ & $\begin{array}{c}4.41 \\
(.68)\end{array}$ & 0.236 \\
\hline Solution & 4.04 & 4.50 & 0.077 \\
\hline Action Plan & $(.40)$ & $(.50)$ & 0.315 \\
\hline Overall & 3.83 & $\begin{array}{l}4.17 \\
(.57)\end{array}$ & 0.126 \\
\hline
\end{tabular}

Note: While all of the comparisons directly favor heterogeneous teams, none are statistically significant at $p<.05$ on these small base sizes. 


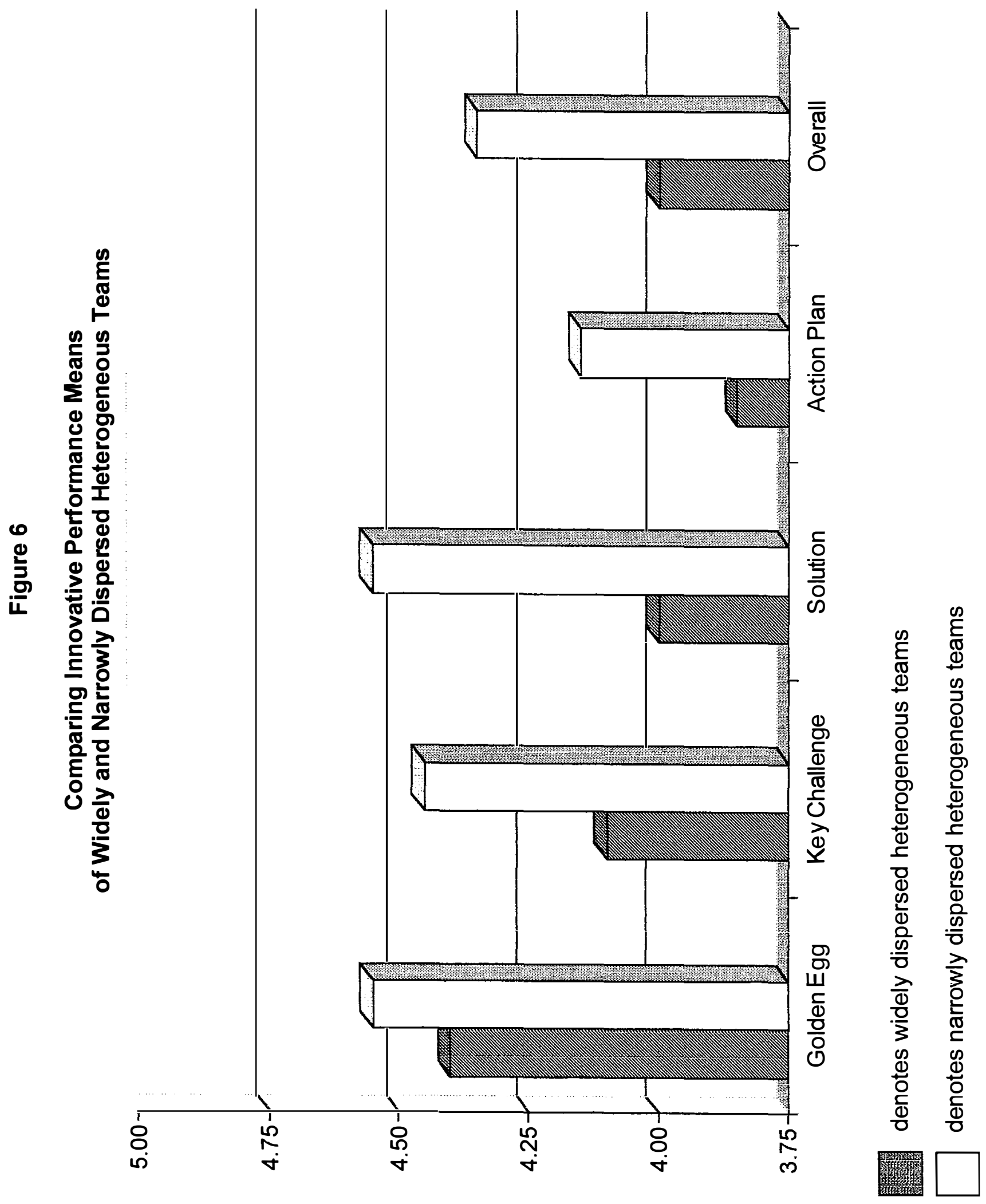


Table 5

Team Satisfaction Index Mean Scores for Team Members

\begin{tabular}{|c|c|c|c|}
\hline $\begin{array}{l}\text { Measures of } \\
\text { Satisfaction }\end{array}$ & $\begin{array}{c}(\mathrm{a}) \\
\text { Teams with } \\
\text { Homogeneous Blends } \\
(\mathrm{n}=85)\end{array}$ & $\begin{array}{c}(b) \\
\text { Teams with } \\
\text { Semi-Homogeneous } \\
\text { Blends } \\
(n=53)\end{array}$ & $\begin{array}{c}(\mathrm{c}) \\
\text { Teams with } \\
\text { Heterogeneous Blends } \\
(n=57)\end{array}$ \\
\hline $\begin{array}{l}\text { Ease of } \\
\text { working } \\
\text { together (Q1) }\end{array}$ & $\begin{array}{c}8.55 \\
(1.03)\end{array}$ & $\begin{array}{l}8.92^{* c} \\
(1.14)\end{array}$ & $\begin{array}{c}8.04 \\
(1.88)\end{array}$ \\
\hline $\begin{array}{l}\text { Enjoyment of } \\
\text { working } \\
\text { together (Q2) }\end{array}$ & $\begin{array}{l}7.56{ }^{* c} \\
(1.44)\end{array}$ & $\begin{array}{c}7.30 \\
(2.18)\end{array}$ & $\begin{array}{c}6.68 \\
(2.20)\end{array}$ \\
\hline $\begin{array}{l}\text { Willingness to } \\
\text { work together } \\
\text { again (Q3) }\end{array}$ & $\begin{array}{l}8.13^{*} \mathrm{c} \\
(1.53)\end{array}$ & $\begin{array}{l}8.47^{* c} \\
(1.46)\end{array}$ & $\begin{array}{c}7.39 \\
(2.20)\end{array}$ \\
\hline $\begin{array}{l}\text { Satisfaction of } \\
\text { output quality } \\
\text { (Q4) }\end{array}$ & $\begin{array}{c}8.31 \\
(1.31)\end{array}$ & $\begin{array}{l}8.64^{* \mathrm{c}} \\
(1.43)\end{array}$ & $\begin{array}{c}7.91 \\
(1.68)\end{array}$ \\
\hline
\end{tabular}

Notes :

${ }^{*} \mathrm{c}$ means significant difference vs heterogeneous (c) at $p<.05$

Q1: How well we worked together (terrible (1) ... excellent (10))

Q2: How much fun I had (none (1) ... a blast (10))

Q3: When I would like to work with this same team again (never (1) ... immediately (10))

Q4: How good do I feel about the quality of our output (awful (1) ... wonderful (10)) 
questions. With due respect to the lack of statistical significance comparing these homogeneity differences, when all of the data are plotted visually (see Figure 7) there is a preliminary hint of an "inverted u" curvilinear relationship among the three types of teams. With only the one exception noted above, all of the lower means are at the left and right poles (homogeneous and heterogeneous), and the higher means are in the center (semi-homogeneous).

\section{DISCUSSION OF RESULTS}

The results of the above study support our first hypothesis, that teams with heterogeneous blends of CPS styles perform better than more homogeneous teams. The results of testing our second hypothesis, while not statistically significant on the small base sizes, do offer encouragement that the effects of differing levels of heterogeneity on team performance are worth exploring further.

Our third hypothesis was supported in that the heterogeneous teams experienced less satisfaction than the homogeneous teams. The possibility that semihomogeneous teams experience an optimal level of satisfaction compared to completely heterogeneous or completely homogeneous teams, that is, that a curvilinear relationship exists between cognitive diversity and satisfaction is very provocative especially since there was a very different relationship between cognitive diversity and performance. Since cognitive diversity was linearly related to performance, it may be that Austin's (1997) notion of an optimal level of group diversity may not relate to creative thinking performance but instead to satisfaction. 
Figure 7

\section{Team Satisfaction Mean Scores}

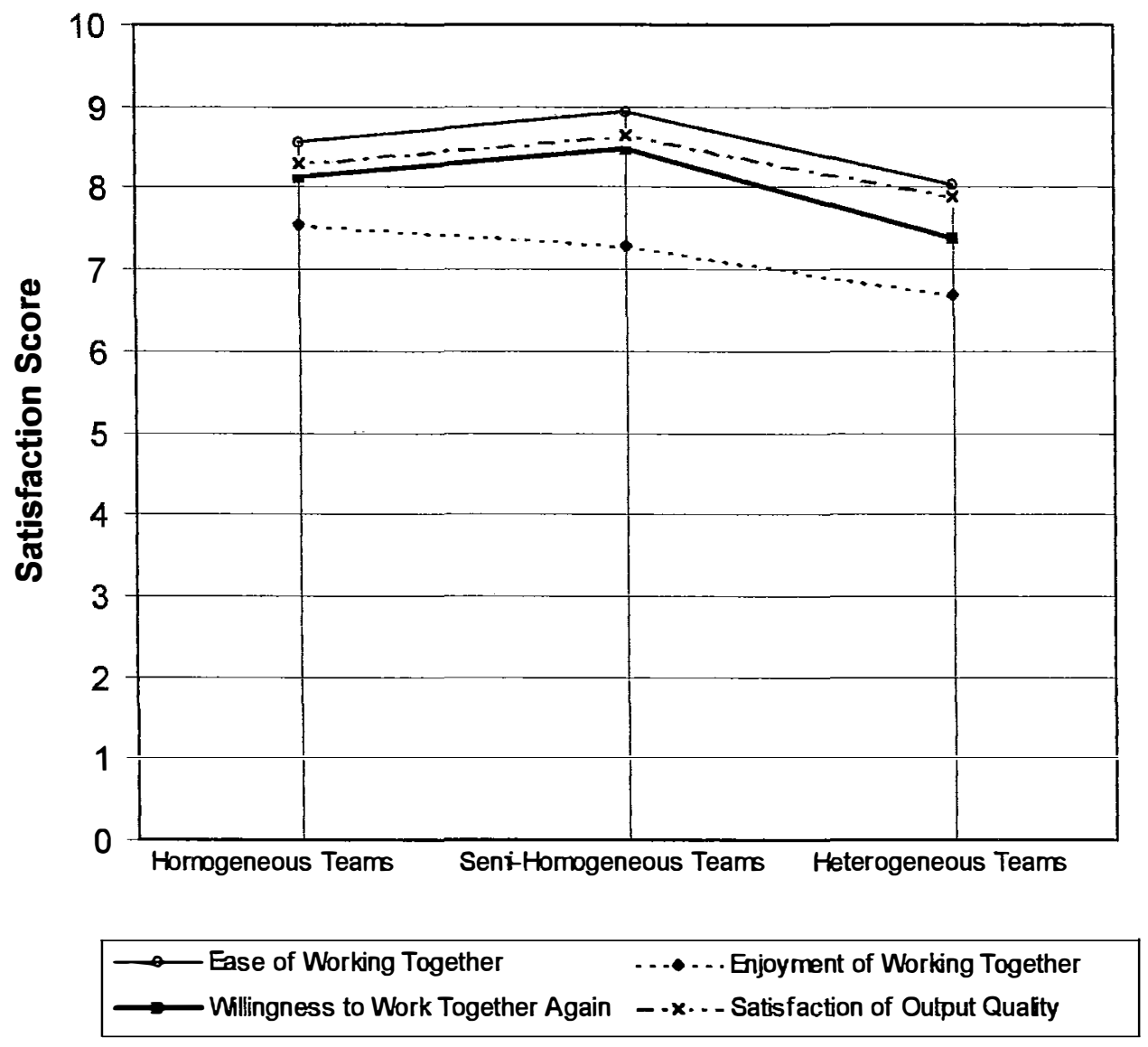


CONCLUSIONS AND FUTURE RESEARCH

It used to be enough for companies to simply concentrate on hiring the best people for each individual position. This is no longer enough to stay ahead of the competition. Today, the most successful companies are those that can create highperformance teams. Advances in network and communication technology have allowed companies to expand their potential team member base by overcoming geographic restrictions. However, this potential increase in team member base does not necessarily translate to the formation of more effective teams. We still need to clearly understand how to best combine individuals. There is some preliminary evidence here that using individuals with diverse cognitive problem solving process preferences and strengths may foster high-performance collaboration, although perhaps not as much satisfaction among team members as less diverse teams.

Future research will expand this study along several dimensions. For further validation of our results, we wish to replicate the above experiment with a larger sample size. In particular, our investigation of dispersion within heterogeneity (hypothesis 2) requires evaluating a larger sample in order to reach any solid conclusions. We would also like to run a similar study among actual organizational teams. Although MBA students are commonly used as an experimental pool in research, differences may arise when replicating studies in a "real world" organizational setting. We are also interested in examining the effects of technology on the performance of teams working within a process framework. For example, can a Group Support System be used to facilitate interaction and understanding among team members that have varying cognitive styles? Can such a system help to build trust among team members and overcome some of the negative satisfaction feelings experienced among diverse groups? As organizations 
increasingly rely on teamwork effectiveness to succeed in today's marketplace, we need

to more fully understand how to best form and support top-performance teams.

\section{REFERENCES}

Austin, J.R. (1997). A Cognitive Framework for Understanding Demographic Influences in Groups. The International Journal of Organizational Analysis, 5 (4), 342-359.

Barlow, C.M. (2000). Deliberate Insight in Team Creativity. Journal of Creative Behavior, 34 (2), Second Quarter, 101-117.

Basadur, M.S. (2000). Evaluating the psychometric improvements provided by Basadur CPSP 2 - Experimental. Management of Innovation and New Technology Research Centre Working Paper No. 99, McMaster University, Hamilton, Ontario, Canada L8S 4M4 (September).

Basadur, M.S. (1998a). The Basadur Simplex creative problem-solving profile inventory: Development, reliability and validity. Management of Innovation and New Technology Research Centre Working Paper No. 83, McMaster University, Hamilton, Ontario, Canada L8S 4M4 (December).

Basadur, M.S. (1998b). Improving the psychometric properties of the Basadur Simplex Creative Problem Solving Profile Inventory. Management of Innovation and New Technology Research Centre Working Paper No. 84, McMaster University, Hamilton, Ontario, Canada L8S 4M4 (December).

Basadur, M.S. (1994). Simplex: A flight to creativity. Buffalo, NY: Creative Education Foundation Press. Spanish title: Simplex: un viaje hacia la creatividad.

Basadur, M.S. (1992). Managing Creativity: A Japanese model. Academy of Management Executive, 6 (2), 29-42.

Basadur, M.S. (1987). Needed research in creativity for business and industrial applications. In Frontiers of Creativity Research: Beyond the Basics. (Editor: Isaksen, S.G., Chapter 18, pp 390-416), Buffalo, NY: Bearly.

Basadur, M.S. (1982). Research in creative problem solving training in business and industry. Proceedings of Creativity Week 4. Greensboro, NC: Center for Creative Leadership.

Basadur, M.S. (1979). Training in creative problem solving: Effects on deferred judgment and problem finding and solving in an industrial research organization. Doctoral Dissertation, University of Cincinnati, December. 
Basadur, M.S. (1974). Think or sink. The Deliberate Methods Change Bulletin, JulySeptember, Procter \& Gamble Management Systems Division, Cincinnati, Ohio.

Basadur, M.S., Graen, G.B., \& Green, S.G. (1982). Training in creative problem solving: Effects on ideation and problem finding in an applied research organization. Organizational Behavior and Human Performance, 30, 41-70.

Basadur, M.S., Graen, G.B., \& Wakabayashi, M. (1990). Identifying individual differences in creative problem solving style. Journal of Creative Behavior, 24 (2).

Belbin, M (1981). Management Teams, Why they Succeed or Fail. London, UK: Heinneman.

Belbin, M. (1993). Team Roles at Work. Oxford: Butterworth Heinemann.

Brophy, D.R. (1998). Understanding, Measuring, and Enhancing Collective Creative Problem-Solving Efforts. Creative Research Journal, 11 (3), 199-229.

Cox, T.H. (1991). The Multicultural Organization. Academy of Management Executive, $5(2), 34-47$.

Cox, T.H. and Blake, S. (1991). Managing Cultural Diversity: Implications for Organizational Competitiveness. Academy of Management Executive, 5 (3), 4556.

Davis, J., Millburn, P., Murphy, T., and Woodhouse, M. (1992). Successful Team Building, How to Create Teams that Really Work. London, UK: Kogan Page.

Filley, A.C. (1975). Interpersonal Conflict Resolution. Glenview Scott Foresman.

Guerin, M.L. (1997). Teamwork at Barton Company: A Psychodynamic Perspective. The 1997 Symposium of The International Society for the Psychoanalytic Study of Organizations.

Guzzo, R.A., Dickson, M.W. (1996). Teams in Organizations: Recent Research on Performance and Effectiveness. Annual Review of Psychology, 47, 307-338.

Hackman, J.R. (1990). Groups that Work (and Those That Don't): Creating Conditions for Effective Teamwork. San Franciso: Jossey-Bass Publishers.

Hirsch, S. (1992). MBTI Team Building Program: Leader's Resource Guide. Consulting Psychologists Press, Inc., USA. 
Jackson, P.W. \& Messick, S. (1964). The Person. the Product and the Response: Conceptual Problems in the Assessment of Creativity. Princeton, NJ: Educational Testing Service.

Janis, I.L. (1971). Group Think. Psychology Today. November.

Kichuk, S.L., Wiesner, W.H. (1998). Work Teams: Selecting Members for Optimal Performance. Canadian Psychology, 39, 23-32.

Kling, J. (2000). Tension in Teams. Harvard Management Communication Letters, July $2000,3 p$.

Margerison, C., and McCann, D. (1990). Team Management, London, UK: W.H. Allen.

Mayer, R.C., Davis, J.H. and Schoorman, F.D. (1995). An Integrative Model of Organizational Trust. The Academy of Management Review, 20 (3), 709-734.

Meyerson, D., Weick, K.E., and Kramer, R.M. (1996). Swift Trust and Temporary Groups. In: R. Kramer T Tyler (Eds.). Trust in Organizations, Thousand Oaks, CA: Sage.

Mumma, F.S. (1994). What Makes Your Team Tick? King of Prussia, PA: HRDQ.

Murdock, M.C. \& Puccio, G.J. (1993). A contextual organizer for conducting creativity research. In S.G. Isaksen, M.C. Murdock, R.L. Firestein, and D.J. Treffinger (Eds.), Nurturing And Developing Creativity: The Emergence Of A Discipline (pp. 249-280). Norwood, NJ: Ablex.

Myers, I.B. (1994). Introduction to Type. ( $5^{\text {th }}$ ed., European English Version.) Oxford: Oxford Psychologists Press.

Nowack, K. (1996). Is the Myers Briggs Type Indicator the Right Tool to Use? Performance in Practice, American Society of Training and Development, Fall 1996, 6.

Nowack, K. (1997). Personality Inventories: The Next Generation. Performance in Practice. American Society of Training and Development, Winter 1996/97.

Osborn, A.F. (1963). Applied Imagination. New York, NY: Charles Scribner's Sons.

Parnes, S.J., Noller, R.B., \& Biondi, A.M. (1977). Guide to Creative Action. New York, NY: Charles Scribner's Sons.

Phillips, S.L., and Elledge, R.L. (1989). The Team Building Source Book. San Diego, CA: University Associates. 
Romig, D., Olson, K. (1995). Empowering Knowledge Teams: The New Frontier of SelfManagement. CSWT 1995 Proceedings.

Rouzes, J.M., Pozner, B.Z. (1988). Leadership Practices Inventory. San Diego, CA: University Associates.

Spencer, J., and Pruss, A. (1992). Managing Your Team. Piatkus.

Woodcock, M. (1989). Team Development Manual. Gower, Aldershot. 


\author{
Appendix I \\ Complete Instructions Provided to Participants in the \\ Team Application of the Simplex Creative Problem Solving Process
}

\title{
Team Assignment
}

Your team's assignment is to use the Simplex process to create a new product or service that solves a problem or satisfies a need in society as a whole. Each team member must be able to contribute significantly to creating this new product or service and moving it toward implementation, based on their past life and work experience. To complete this assignment your team will work its way through the first six steps of the SIMPLEX process. Your output will include: (1) a selected problem or unsatisfied need (a fuzzy situation); (2) a clearly defined problem or unsatisfied need; (3) a clear and specific solution (product or service); (4) a clear, specific action plan for moving the new product or service to implementation. All four of these will be evaluated by a panel of judges. These judges are experienced managers of local industries. While there is no grade assigned, the teams with the best results will be publicly recognized.

\section{The four evaluation criteria will be:}

1. The clarity and importance of the selected problem or unsatisfied need (golden egg) (from step 1).

2. The clarity and innovativeness of the defined problem or unsatisfied need (the key challenge selected from Step 3).

3. The clarity and innovativeness of your selected solution (the best product or service idea emerging from Step 5).

4. The quality of the action plan (its specificity, likelihood of real world implementation, and degree of involvement of each team member) emerging from Step 6.

\section{The Process Application:}

Step 1: Proactive Problem Finding

- Generate a list of problems and unsatisfied needs that people might be having (divergence) - use the special Problem Finding form to help you.

- Select one that you feel has the most potential for a new innovative business product or service. (convergence)

\section{Step 2: Fact Finding}

- Generate a list of possible relevant facts using the six fact finding questions. Make sure your fact finding covers both your overall team assignment and your selected problem/unsatisfied need (divergence) - use the special Fact Finding form to help you.

- Select those key facts that your team believes are the most important, intriguing, revealing, interesting, etc. (convergence) 


\section{Appendix I continued}

\section{Step 3: Problem Definition}

Part A

- Generate a list of challenges based on your key facts, each starting with the words "How Might We Help People (HMWHP)...?" (divergence)

- Select a key challenge (or more than one if it makes sense) to begin your challenge Map. (convergence)

Part B

- Generate a Challenge Map using the "Why-What's Stopping?" Analysis on your beginning key challenge(s). Ask the "else" question frequently! (divergence)

- Select the one key challenge from your map that excites your team as the most clearly defined and innovative. (convergence)

\section{Step 4: Idea Finding}

- Generate potential solutions to the one key challenge you selected. (divergence)

- Select a small number of potential solutions that are your best bets as a new product or service that solves the key challenge. (convergence)

\section{Step 5: Evaluation and Selection}

- Generate criteria which might be relevant to judging your best bet solutions. (divergence)

- Select the most relevant criteria. (convergence)

- Put your selected best bet solutions and most relevant criteria on a criteria grid and evaluate your solutions.

- Select your single best solution (or combination of solutions), which will be the product or service you have created.

\section{Step 6: Action Plan}

- Generate as many small, simple, specific steps your team members might take just to get the ball rolling on moving your solution toward reality. (divergence)

- Pick the very first step someone in your group will commit to undertake and write it in the "What" column of your action plan. Then write specifically how that person will do the what in the "How" column. Write the person's full name in the "Who" column and exactly when (date and time) and where (specific location) this action will take place in the "When" and "Where" columns.

- Complete your action plan with at least three or four additional action steps that would need to be taken after the first step (or before the first step; you may find that the first step you picked is not really the first one).

\section{Reporting}

Fill in Team Assignment Summary Sheet and hand in. 


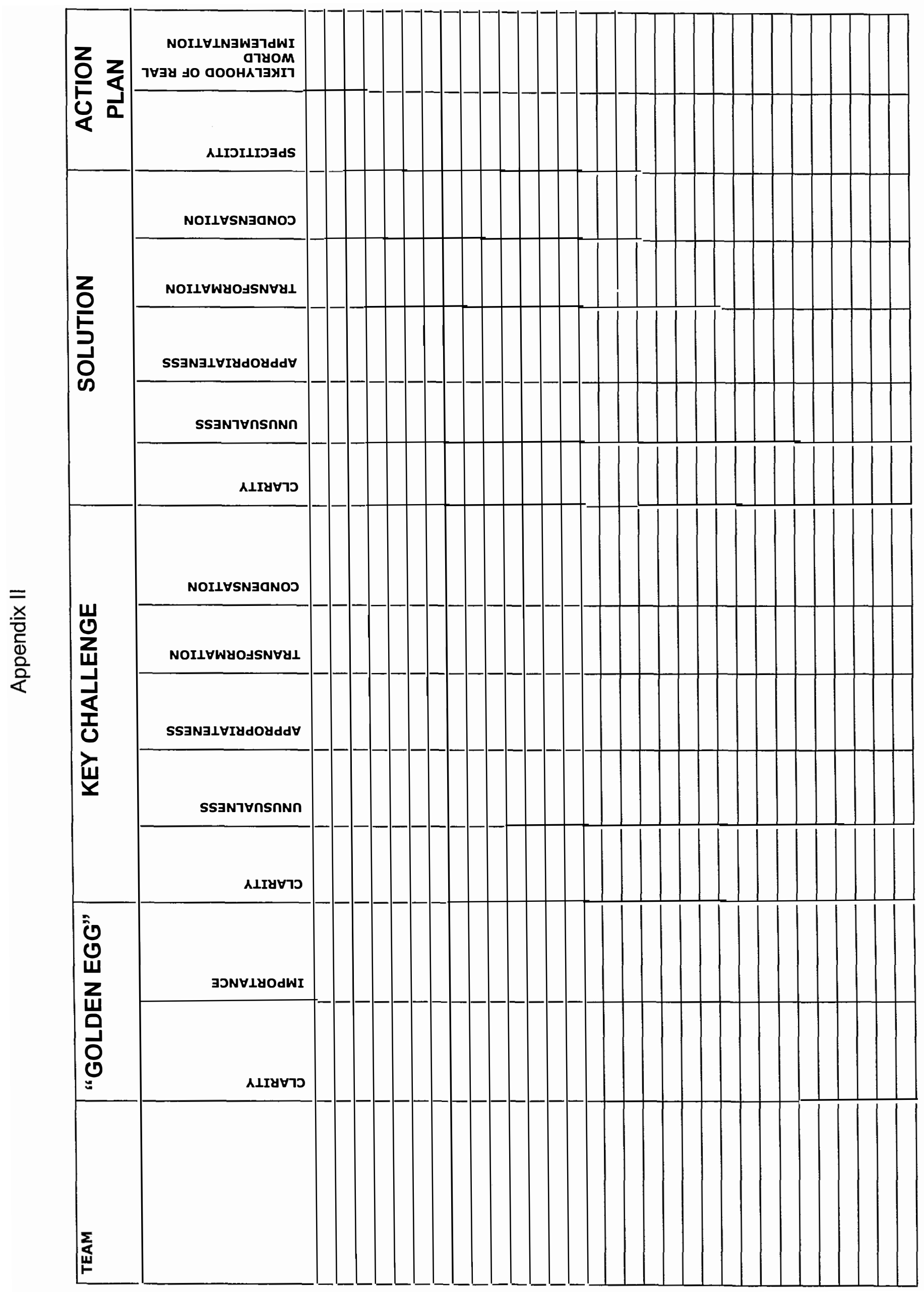




\section{MANAGEMENT OF INNOVATION AND NEW TECHNOLOGY WORKING PAPER SERIES}

1. R.G. Cooper and E.J. Kleinschmidt, "How the New Product Impacts on Success and Failure in the Chemical Industry", February, 1992.

2. R.G. CooperandE.J. Kleinschmidt, "Major New Products: What Distinguishes the Winners in the Chemical Industry", February, 1992.

3. J. Miltenburg, "On the Equivalence of JIT and MRP as Technologies for Reducing Wastes in Manufacturing, March, 1992.

4. J.B. Kim, I. Krinsky and J. Lee, "Valuation of Initial Public Offerings: Evidence from Korea", February, 1992.

5. M. Basadur and S. Robinson, "The New Creative Thinking Skills Needed for Total Quality Management to Become Fact, Not Just Philosophy", April, 1992.

6. S. Edgett and S. Parkinson, "The Development of New Services Distinguishing Between Success and Failure", April, 1992.

7. A.R. Montazemi and K.M. Gupta, "Planning and Development of Information Systems Towards Strategic Advantage of a Firm", April, 1992.

8. A.R. Montazemi, "Reducing the Complexity of MIS Innovation Through Hypermedia and Expert Systems", May, 1992.

9. M. Basadur and Bruce Paton, "Creativity Boosts Profits in Recessionary Times - Broadening the Playing Field", June, 1992.

10. Robert G. Cooper and Elko Kleinschmidt, "Stage-Gate Systems for Product Innovation: Rationale and Results", June, 1992.

11. S.A.W. Drew, "The Strategic Management of Innovation in the Financial Services Industry: An Empirical Study", July, 1992.

12. M. Shehata and M.E. Ibrahim, "The Impact of Tax Policies on Firms' R \& D Spending Behavior: The Case of R \& D Tax Credit", July, 1992. 
13. Willi H. Wiesner, "Development Interview Technology: Implications for Innovative Organizations", July, 1992.

14. Isik U. Zeytinoglu, "Technological Innovation and the Creation of a New Type of Employment: Telework", August, 1992.

15. John W. Medcof, "An Integrated Model for Teaching the Management of Innovation in the Introduction to Organizational Behaviour Course", October, 1992.

16. Min Basadur, "The Why-What's Stopping Analysis: A New Methodology for Formulating Ill-Structured Problems", October, 1992.

17. Stephen A.W. Drew, "Strategy, Innovation and Organizational Learning an Integrative Framework, Case Histories and Directions for Research", November, 1992.

18. Stephen A.W. Drew, "Innovation and Strategy in Financial Services", November, 1992.

19. Scott Edgett, "New Product Development Practices for Retail Financial Services", November, 1992.

20. Robert G. Cooper and Elko J. Kleinschmidt, "New Product Winners and Losers: The Relative Importance of Success Factors - Perception vs. Reality", November, 1992.

21. Robert G. Cooper and Elko J. Kleinschmidt, "A New Product Success Factors Model: An Empirical Validation", November, 1992.

22. Robert G. Cooper \& Elko J. Kleinschmidt, "Stage Gate Systems: A Game Plan for New Product Success", November, 1992.

23. Min Basadur, "Optimal Ideation-Evaluation Ratios", March, 1993.

24. Christopher K. Bart, "Gagging on Chaos", March, 1993.

25. Yufei Yuan, "The Role of Information Technology in Business Innovation", July, 1993.

26. Isik Urla Zeytinoglu, "Innovation in Employment: A Telework Experiment in Ontario", July, 1993.

27. John Miltenburg and David Sparling, "Managing and Reducing Total Cycle Time: Models and Analysis", August, 1993.

28. R.G. Cooper, C.J. Easingwood, S. Edgett, E.J. Kleinschmidt and C. Storey, "What Distinguishes the Top Performers in Financial Services", September, 1993.

29. B.E. Lynn, "Innovation and Accounting Research", September, 1993. 
30. Min Basadur and Peter Hausdorf, "Measuring Additional Divergent Thinking Attitudes Related to Creative Problem Solving and Innovation Management", November, 1993.

31. R.G. Cooper and E.J. Kleinschmidt, "Determinants of Time Efficiency in Product Development", December, 1993.

32. Christopher K. Bart, "Back to the Future: Timeless Lessons for Organizational Success", February, 1994.

33. Ken R. Deal and Scott J. Edgett, "Determining Success Criteria for New Financial Products; A Comparative Analysis of CART, Logit and Discriminant Analysis", February, 1995.

34. Christopher K. Bart and Mark C. Baetz, "Does Mission Matter?", February, 1995.

35. Christopher K. Bart, "Controlling New Products: A Contingency Approach", February, 1995.

36. Christopher K. Bart, "Is Fortune Magazine Right? An Investigation into the Application of Deutschman's 16 High-Tech Management Practices", February, 1995.

37. Christopher K. Bart, "The Impact of Mission on Firm Innovativeness", February, 1995.

38. John W. Medcof, "Transnational Technology Networks", April, 1995.

39. R.G. Cooper and E.J. Kleinschmidt, "Benchmarking the Critical Success Factors of Firms' New Product Development Programs", April, 1995.

40. John W. Medcof, "Trends in Selected High Technology Industries", July, 1995.

41. Robert C. Cooper \& E.J. Kleinschmidt, "Benchmarking Firms' New Product Performance \& Practices", September, 1995.

42. Min Basadur and Darryl Kirkland, "Training Effects on the Divergent Thinking Attitudes of South American Managers", November, 1995.

43. Min Basadur, "Organizational Development Interventions for Enhancing Creativity in the Workplace", November, 1995.

44. Min Basadur, "Training Managerial Evaluative and Ideational Skills in Creative Problem Solving: A Causal Model", December, 1995. 
45. Min Basadur, Pam Pringle and Simon Taggar, "Improving the Reliability of Three New Scales Which Measure Three New Divergent Thinking Attitudes Related to Organizational Creativity", December, 1995.

46. N. P. Archer and F. Ghasemzadeh, "Project Portfolio Selection Techniques: A Review and a Suggested Integrated Approach", February, 1996.

47. Elko J. Kleinschmidt, "Successful new product development in Australia: An empirical analysis", February, 1996.

48. Christopher K. Bart, "Industrial Firms \& the Power of Mission," April, 1996.

49. N. P. Archer and F. Ghasemzadeh, "Project Portfolio Selection Management through Decision Support: A System Prototype," April, 1996.

50. John W. Medcof, "Challenges in Collaboration Managementin Overseas Technology Units," April, 1996.

51. Susan L. Kichuk and Willi H. Wiesner, "Personality and Team Performance: Implications for Selecting Successful Product Design Teams," May, 1996.

52. Susan L. Kichuk and Willi H. Wiesner, "Selection Measures for a Team Environment: The Relationships among the Wonderlic Personnel Test, The Neo-FFI, and the Teamwork KSA Test, " May, 1996.

53. Susan L. Kichuk and Willi H. Wiesner, "Personality, Performance, Satisfaction, and Potential Longevity in Product Design Teams," June, 1996.

54. John W. Medcof, "Learning, Positioning and Alliance Partner Selection,” June, 1996.

55. Scott J. Edgett, "The New Product Development Process for Commercial Financial Services," July, 1996.

56. Christopher K. Bart, “Sex, Lies \& Mission Statements,” September, 1996.

57. Stuart Mestelman and Mohamed Shehata, "The Impact of Research and Development Subsidies on the Employment of Research and Development Inputs," November, 1996.

58. Mark C. Baetz and Christopher K. Bart, "Developing Mission Statements Which Work," November, 1996.

59. Fereidoun Ghasemzadeh, Norm Archer and Paul Iyogun, "A Zero-One Model for Project Portfolio Selection and Scheduling," December, 1996. 
60. R. G. Cooper, S. J. Edgett, E. J. Kleinschmidt, "Portfolio Management in New Product Development: Lessons from Leading Firms," February 1997.

61. R. G. Cooper, S. J. Edgett, E. J. Kleinschmidt, "Portfolio Management in New Product Development: Lessons from Leading Firms -- Part II," February 1997.

62. C. K. Bart, "A Comparison of Mission Statements \& Their Rationales in Innovative and Non-Innovative Firms," February 1997.

63. R. Bassett, N. P. Archer and W. G. Truscott, "Data Webs: An Evaluation of an Innovative Information Management Tool that Integrates Databases with the World Wide Web," April 1997.

64. S. Taggar, "Intelligence, Personality, Creativity and Behaviour: The Antecedents of Superior Team Performance," April 1997.

65. R. Deaves and I. Krinsky, "New Tools for Investment Decision-Making: Real Options Analysis," May 1997.

66. J. W. Medcof (ed.), "Trends and Events in Selected High Technology Industries," May, 1997. (On the WEB only)

67. C. K. Bart, "Product Innovation Charters: A State-of-the-Art Review," May, 1997.

68. John W. Medcof, "Strategic Contingencies and Power in Networks of Internationally Dispersed R\&D Facilities", August, 1997.

69. John W. Medcof, "Research Intensity and the Identification of High Technology Industries," September, 1997.

70. Christopher K. Bart and John C. Tabone, "Mission Statements in the Not-for-profit Health Care Sector: A State of the Art Review," September, 1997.

71. Elko J. Kleinschmidt, "In-house and Partnership New Product Development in Austria: An Empirical Analysis on Outcome and Explanatory Factors," October, 1997.

72. Robert G. Cooper, Scott J. Edgett and Elko J. Kleinschmidt, "R\&D Portfolio Management Best Practices: Methods Used \& Performance Results Achieved," January, 1998.

73. Christopher K. Bart and Simon Taggar, "A Model of the Impact of Mission Rationale, Content, Process and Alignment on Firm Performance," March, 1998.

74. Christopher K. Bart, John Parkinson and Simon Taggar, "The Implementation of Strategy: Behavioural vs Budgetary Approaches and the Effect of Participation," March, 1998. 
75. John W. Medcof, "The Resource Based View and the New Competitive Landscape: Characterizing Positions of Dynamic Capability," May, 1998.

76. F. Ghasemzadeh and N. P. Archer, "Project Portfolio Selection Through Decision Support," June, 1998.

77. Y. Yuan, N. Archer, and R. Bassett, "The Impact of Electronic Commerce Innovations on Marketing Management," June, 1998.

78. Kenneth S. Chan, James Chowhan, Stuart Mestelman, Mohamed Shehata, "Value Orientations and Income and Displacement Effects," July 1998.

79. Min Basadur, Laurent Lapierre, "Predicting Creative Problem Solving Behaviors within Teams," September, 1998.

80. Min Basadur, "Simplex: Modelling the Phases and Stages of the Innovation Process in OpenSystem Organizations", October, 1998.

81. Ken Deal, Ben Long and Bryan Scott, "New Pricing Product Design for Competitive Advantage", November, 1998.

82. Min Basadur, Mark A. Runco and Luis A. Vega, "Understanding How Creative Thinking Skills, Attitudes and Behaviors Work Together in Real World Managerial Problem Solving," November, 1998.

83. Min Basadur, "The Basadur Simplex Creative Problem-Solving Profile Inventory: Development, Reliability and Validity", December, 1998.

84. Min Basadur, "Improving the Psychometric Properties of the Basadur Simplex Creative Problem Solving Profile Inventory," December, 1998.

85. Min Basadur, "Discovering the Right Questions about the Management of Technology Using Challenge Mapping," December, 1998.

86. Nick Bontis, "Managing an Organizational Learning System by Aligning Stocks and Flows of Knowledge: An Empirical Examination of Intellectual Capital, Knowledge Management, and Business Performance," January, 1999.

87. Nick Bontis and John Girardi, "Teaching Knowledge Management and Intellectual Capital Lessons: An Empirical Examination of the Tango Simulation," January, 1999.

88. Karen Boehnke, Nick Bontis, Joseph J. DiStefano and Andrea C. DiStefano, "Transformational Leadership: An Examination of Cross-Cultural Differences and Similarities," January, 1999. 
89. John W. Medcof, "The Resource Based View and Transnational Technology Strategy," May 1999.

90. Harish C. Jain and Parbudyal Singh, "Innovative Recruitment and Selection Strategies for Visible Minority Police Officers in Selected Canadian Police Organizations," June 1999.

91. Laurent M. Lapierre, "The Measurement of Transformational Leadership Revisited: Confirming the MLQ factor Structure in Autonomous Work Teams, October 1999.

92. Naresh C. Agarwal and Parbudyal Singh, "Organizational Change, Innovation and Reward Systems: A Look at Theory and Practice," December 1999.

93. Nick Bontis and Jason Mill, "Web-Based Metrics and Internet Stock Prices," January 2000.

94. Nick Bontis and Honsan Chung, "Software Pricing Structures in Electronic Commerce: 3 Different Cases," January 2000.

95. John W. Medcof, "Resource Based Strategy and Managerial Power in Networks of Internationally Dispersed Technology Units," January 2000.

96. John W. Medcof, “Dynamic Capabilities: A Neo-Contingency Theory?”, January 2000.

97. John W. Medcof, "On the Road to the New Business Paradigm: How Far is too Far?", January 2000.

98. Michael H. Mitchell and Nick Bontis, “A CKO's Raison D'etre: Driving Value-Based Performance Gains by Aligning Human Capital with Business Strategy," January 2000.

99. Min Basadur, "Evaluating the Psychometric Improvements Provided by Basadur CPSP 2Experimental," September 2000.

100. Min Basadur, "The Economic, Social and Psychological Outcomes of Implementing a Deliberate Process of Organizational Creativity," December 2000.

101. Nick Bontis, Michael Fearon and Marissa Hishon, "The E-Flow Audit: An Evaluation of EMail Flow within and Outside a High-Tech Firm," January 2001.

102. Neel Chauhan and Nick Bontis, "Organizational Learning Via Groupware: a Path to Discovery or Disaster?", January 2001.

innova/papers.irc 
Imnishel

HD

45

- 10657

no. 103 